\title{
IMPLIKASI PIJAT BAYI TERHADAP PENINGKATAN BERAT BADAN PADA BAYI USIA 6-8 BULAN
}

\author{
Prodalima $^{1}$, Delfriana Ayu A ${ }^{2}$ \\ ${ }^{1}$ Sekolah Tinggi Ilmu Kesehatan Nurul Hasanah Kutacane Kabupaten Aceh \\ Tenggara \\ JIn. Ahmad Yani, Pulo Kemiri Kecamatan Babussalam \\ Kutacane, Kabupaten Aceh Tenggara Proinsi Aceh \\ e-mail : prodalima@gmail.com \\ ${ }^{2}$ Fakultas Kesehatan Masyarakat Universitas Islam Negeri Sumatera \\ Utara
}

DOI: https://doi.org/10.35451/jkf.v1i2.136

\begin{abstract}
Infant massage has been practiced almost all over the world since ancient times, including Indonesia. Baby massage art is taught hereditary although it is not known clearly how massage and touch can have a positive effect on the human body. Baby massage can be classified as a touch stimulation application, because in the baby massage there is a touch element in the form of affection, attention, voice or speech, eye sight, movement, and massage. This stimulation will stimulate the development of the structure and function of brain cells. This research type is quantitative by using Quasi Experimental design without control group with One Group Pre Test and Post Test Design method. Researchers made treatment of one study subject alone, by performing pre-test and postintervention testing. This research was conducted in Kute Bakti, Babul Makmur Subdistrict, Southeast Aceh Regency. The sampling technique using total sampling technique thus, the researchers took a sample of the entire population of as many as 12 babies. The result of this study showed that based on the age of the infant, the age of 8 months was 6 people (50\%), 7 months old 4 people $(37,5 \%)$ and age 6 months, $2(16,7 \%)$. Based on the sex of the baby, the most male sex is as many as 8 people (66.6\%) and women as many as 4 people $(33.3 \%)$. Based on the education of parents, most high school education that is as much as 7 people (58.3\%) and junior high as 5 people (41.7\%). The test results obtained value $P=0.07(P<0.05)$ in other words there is ingcraesing baby's weight after the baby massage therapy with the average weight baby weight of $1.05 \mathrm{~kg}$. The results showed that the use of infant massage therapy has implications for infant weight gain, therefore the results of this study is expected to be information and input for educational institutions and nursing professions, especially nursing children and nursing maternity as well as evidence base in improving the baby's weight both in theory or practice.
\end{abstract}

Keywords: Baby Massage, Weight Gain

\section{PENDAhuluan}

Memilik anak dengan tumbuh kembang yang optimal adalah dambaan setiap orang tua. Proses tumbuh kembang anak dapat berlangsung secara alami. Istilah tumbuh kembang sebenarnya mencakup dua peristiwa yang sifatnya berbeda, tetapi saling berkaitan dan sulit dipisahkan, yaitu pertumbuhan dan perkembangan. Pertumbuhan berkaitan dengan masalah perubahan dalam besar, jumlah, ukuran atau dimensi tingkat sel, organ maupun individu, yang bisa diukur dengan 
ukuran berat (gram, pound, kilogram), ukuran panjang (cm, meter), umur tulang dan keseimbangan metabolic (retensi kalsium dan nitrogen tubuh). Perkembangan adalah bertambahnya kemampuan dalam struktur dan fungsi tubuh yang lebih kompleks dalam pola yang teratur dan dapat diramalkan, sebagai proses pematangan (Soetjiningsih, 2014).

Tercapainya pertumbuhan dan perkembangan yang optimal merupakan hasil interaksi berbagai faktor yang saling berkaitan, yaitu faktor genetik, lingkungan dan perilaku, serta rangsangan atau stimulasi yang berguna. Perilaku orang tua juga sangat berpengaruh dalam tumbuh kembang anak terutama pada pemberian gizi oleh orang tua. Pemberian gizi tentu saja paling berpengaruh dan bisa terlihat pada pengukuran berat badan. Status gizi yang optimal pada bayi dua tahun kehidupan pertama merupakan salah satu penentu kualitas sumber daya pada masyarakat sehingga penanganan tepat pada awal pertumbuhan akan mencegah gangguan gizi yang dapat muncul saat dewasa (Adriani And Wirjatmadi, 2014).

Berat badan bayi sangat dipengaruhi oleh faktor keturunan, gizi, lingkungan, jenis kelamin, status sosial. Berat badan salah satu indikator antropometrik untuk menilai tumbuh pada bayi atau anak. Ada beberapa cara yang dapat dilakukan untuk menaikkan berat badan bayi yaitu memberikan gizi yang baik (Chomaria, 2015).

RISKESDAS (2013) menyatakan secara nasional, prevalensi beratkurang pada tahun 2013 adalah 19,6 persen, terdiri dari 5,7 persen gizi buruk dan 13,9 persen gizi kurang. Jika dibandingkan dengan angka prevalensi nasional tahun 2007 (18,4\%) dan tahun $2010(17,9 \%)$ terlihat meningkat. Perubahan terutama pada prevalensi gizi buruk yaitu dari 5,4 persen tahun 2007, 4,9 persen pada tahun 2010, dan 5,7 persen tahun 2013. Sedangkan prevalensi gizi kurang naik sebesar 0,9 persen dari 2007 dan 2013.

Kenaikan berat badan bayi pada tahun pertama kehidupan apabila anak mendapat gizi yang baik yaitu dari bayi lahir sampai 6 bulan pertama pertambahan berat badan setiap minggu 140-200 gram. Berat badan bayi menjadi 2 kali lipat berat badan lahir pada akhir 6 bulan pertama. Sedangkan pada umur 6-12 bulan pertambahan berat badan setiap minggu berkisar antara 85-400 gram. Berat badan akan meningkat sebesar 3 kali berat badan lahir pada akhir tahun pertama (Hidayat, 2008).

Pijat melibatkan kerja dan gerak pada tubuh dengan tekanan yang terstruktur, tidak terstruktur, stasoner atau gerakan dengan tekanan, gerakan dengan getaran, bisa dilakukan secara manual atau dengan bantukan alat. Pijat dapat dilakukan denga tangan, jari, siku, lutut, lengan, kaki atau perangkat pemijatan lainnya. Pemijatan dapat memberikan relaksasi, perasaan tenak, bisa menjadi aktivitas rekreasi. Dalam pelaksanannya pijat bisa dilakukan sambil berbaring di meja pijat, duduk di kursi pijat, berbaring diatas tikar, ditempat tidur ataupun di lantai. Adapun juga jenis pijat diair, pijat ini biasa dilakukan dengan berendam atau mengambang dikolam dengan air hangat. Subjek pijat mungkin bisasepenuhnya memakan pakian, sebagian berpakaian ataupun tidak berpakaian. (Wong, 2009)

Hasil penelitian yang dilakukan oleh Irva (2014) di wilayah kerja Puskesmas (Posyandu) Harapan Raya Pekanbaru terhadap 17 bayi menunjukkan bahwa mayoritas berada pada usia 4-6 bulan dengan jumlah 16 bayi dan mayoritas berjenis kelamin laki-laki. Median berat badan bayi pada kelompok eksperimen setelah diberikan terapi pijat sebesar 5600 dan pada kelompok kontrol sebesar 4500 berdasarkan uji dari uji Mann-Whitney didapatkan $\mathrm{p}$ value sebesar $0,01 \quad(p<0,05) \quad$ sehingga pemberian terapi pijat berpengaruh terhadap peningkatan berat badan bayi.

\section{METODE PENELITIAN}

Desain penelitian ini adalah kuantitatif dengan menggunakan pendekatan Quasy Eksperiment tanpa kelompok kontrol dengan metode One 
Group Pre Test And Post Test Design. Jumlah populasi dalam penelitian ini sebanyak 12 bayi dengan teknik pengambilan sampel menggunakan teknik Total Sampling. Lokasi penelitian ini berada di desa Kute Bakti Kecamatan Babul Makmur Kabupaten Aceh Tenggara. Penelitian ini dilakukan pada bulan Oktober-Nopember 2018.

3. HASIL PENELITIAN

Tabel 1.1. Distribusi

Frekuensi Dan Persentase Karateristik Responden $(n=12)$

\begin{tabular}{|c|c|c|}
\hline \multirow{2}{*}{\multicolumn{3}{|c|}{$\begin{array}{l}\text { Karateristik } \\
\text { Usia Bayi }\end{array}$}} \\
\hline & & \\
\hline 6 Bulan & 2 & 16,7 \\
\hline 7 Bulan & 4 & 33,3 \\
\hline 8 Bulan & 6 & 50 \\
\hline Total & 12 & 100 \\
\hline Jenis Kelamin & & \\
\hline Bayi & 8 & 66,7 \\
\hline Laki-Laki & 4 & 33,3 \\
\hline Perempuan & & \\
\hline Total & 12 & 100 \\
\hline Pendidikan Orang & & \\
\hline Tua & 0 & 0 \\
\hline SD & 5 & 41,7 \\
\hline SMP & 7 & 58,3 \\
\hline SMA & & \\
\hline Total & 12 & 100 \\
\hline Pekerjaan Orang & & \\
\hline Tua & 0 & 0 \\
\hline Tidak Bekerja & 2 & 16,7 \\
\hline PNS & 1 & 8,3 \\
\hline Pegawai Swasta & 9 & 75 \\
\hline Petar & 12 & 100 \\
\hline
\end{tabular}

Berdasarkan tabel diatas, paling banyak usia bayi berada pada usia 8 bulan yaitu sebanyak 6 orang (50\%), usia 7 bulan yaitu sebanyak 4 orang $(37,5 \%)$ dan usia 6 bulan yaitu sebanyak 2 orang $(16,7 \%)$. Berdasarkan jenis kelamin bayi, paling banyak berjenis kelamin laki-laki yaitu sebanyak 8 orang $(66,6 \%)$ dan perempuan sebanyak 4 orang $(33,3 \%)$. Berdasarkan pendidikan orang tua, paling banyak berpendidikan SMA yaitu sebanyak 7 orang $(58,3 \%)$ dan SMP sebanyak 5 orang $(41,7 \%)$. Berdasarkan pekerjaan orang tua, paling banyak bekerja sebagai petani yaitu sebanyak 9 orang $(75 \%)$, PNS sebanyak
2 orang $(16,7 \%)$ dan pegawai swasta yaitu sebanyak 1 orang $(8,3 \%)$.

Tabel 1.2.1.Distribusi Frekuensi dan Persentasi Berat Badan Bayi Berjenis Kelamin Laki-Laki Pre-test $(\mathrm{n}=8)$

\begin{tabular}{lll}
\hline Var Usia & n $\%$
\end{tabular}

\begin{tabular}{cccccc} 
BB & $\mathbf{6}$ & $\mathbf{7}$ & $\mathbf{8}$ & & \\
& Bln & Bln & Bln & & \\
$\mathbf{6 , 5}$ & 1 & - & - & 1 & 8,3 \\
$\mathbf{K g}$ & & & & & \\
$\mathbf{6 , 8}$ & - & 4 & & 4 & 33,3 \\
$\mathbf{K g}$ & & & & 3 & 25 \\
$\mathbf{7 , 2}$ & - & - & 3 & & \\
$\mathbf{K g}$ & & & & $\mathbf{8}$ & $\begin{array}{c}\mathbf{7 6} \\
\mathbf{6}\end{array}$ \\
\hline
\end{tabular}

Berdasarkan pengukuran berat badan bayi berjenis kelamin laki-laki sebelum dilakukan tindakan didapatkan data bahwa usia bayi 6 bulan dengan berat badan berat badan $6,5 \mathrm{Kg}$ sebanyak 1 bayi $(8,3 \%)$ usia 7 bulan dengan berat dan $6,8 \mathrm{Kg}$ sebanyak 4 bayi dan usia 8 bulan dengan berat badan bayi 7,2 Kg sebanyak 3 orang (25\%).

Tabel 1.2.2. Distribusi Frekuensi dan Persentasi Berat Badan Bayi Berjenis Kelamin Perempuan Pre-test $(n=4)$

\begin{tabular}{|c|c|c|c|c|c|}
\hline \multirow{3}{*}{$\begin{array}{l}\text { Var } \\
\text { BB }\end{array}$} & \multicolumn{3}{|c|}{ 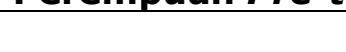 } & \multirow{3}{*}{$\mathbf{n}$} & \multirow{3}{*}{$\%$} \\
\hline & \multicolumn{3}{|c|}{ Usia } & & \\
\hline & $\begin{array}{c}6 \\
\text { BIn }\end{array}$ & $\begin{array}{c}7 \\
\text { BIn }\end{array}$ & $\begin{array}{c}8 \\
\text { Bln }\end{array}$ & & \\
\hline $\begin{array}{l}5,7 \\
\mathrm{Kg}\end{array}$ & 1 & - & - & 1 & 8,3 \\
\hline $\begin{array}{l}6,2 \\
\mathrm{Kg}\end{array}$ & - & 2 & - & 2 & 16,7 \\
\hline $\begin{array}{l}6,6 \\
\mathrm{Kg}\end{array}$ & - & - & 1 & 1 & 8,3 \\
\hline \multicolumn{4}{|c|}{ Total } & 4 & $\begin{array}{c}33 \\
3\end{array}$ \\
\hline
\end{tabular}

Berdasarkan pengukuran berat badan bayi berjenis kelamin perempuan sebelum dilakukan tindakan didapatkan data bahwa usia bayi 6 bulan dengan berat badan berat badan $5,7 \mathrm{Kg}$ sebanyak 1 bayi $(8,3 \%)$, usia 7 bulan dengan berat dan $6,2 \mathrm{Kg}$ sebanyak 2 bayi $(16,7 \%)$ dan usia 8 bulan dengan berat badan bayi $6,6 \mathrm{Kg}$ sebanyak 1 orang $(8,3 \%)$. 
Tabel 1.3.1. Distribusi Frekuensi dan Persentasi Berat Badan Bayi Berjenis Kelamin Laki-Laki Posttest $(n=8)$

\begin{tabular}{|c|c|c|c|c|c|}
\hline Var & & Usia & & $\mathbf{n}$ & $\%$ \\
\hline BB & $\begin{array}{c}6 \\
\text { BIn }\end{array}$ & $\begin{array}{c}7 \\
\text { BIn }\end{array}$ & $\begin{array}{c}8 \\
\text { Bln }\end{array}$ & & \\
\hline $\begin{array}{l}6,6 \\
\mathrm{Kg}\end{array}$ & 1 & - & - & 1 & 8,3 \\
\hline $\begin{array}{c}6,9 \\
\mathrm{Kg}\end{array}$ & - & 4 & & 4 & $\begin{array}{c}33 \\
3\end{array}$ \\
\hline 7,3 & - & - & 3 & 3 & 25 \\
\hline \multicolumn{4}{|c|}{ Total } & 8 & $\begin{array}{r}76 \\
, 6 \\
\end{array}$ \\
\hline
\end{tabular}

Berdasarkan tabel diatas, setelah dilakukannya terapi pijat bayi kepada bayi berjenis kelamin laki-laki didapatkan hasilnya bahwa bayi usia 6 bulan sebanyak 1 bayi $(8,3 \%)$ dengan berat badan yaitu $6,6 \mathrm{Kg}$, bayi usia 7 bulan sebanyak 4 bayi $(33,3 \%)$ dengan berat badan yaitu $6,9 \mathrm{Kg}$ dan bayi usia 8 bulan sebanyak 3 bayi (25\%) dengan berat badan yaitu $7,3 \mathrm{Kg}$.

Tabel 1.3.2. Distribusi Frekuensi dan Persentasi Post-test Berat Badan Bayi Berjenis Kelamin Perempuan $(n=4)$

\begin{tabular}{|c|c|c|c|c|c|}
\hline \multirow{2}{*}{$\begin{array}{l}\text { Var } \\
\text { BB }\end{array}$} & \multicolumn{3}{|c|}{ Usia } & \multirow{2}{*}{$\mathbf{n}$} & \multirow{2}{*}{$\%$} \\
\hline & $\begin{array}{c}6 \\
\text { BIn }\end{array}$ & $\begin{array}{c}7 \\
\text { BIn }\end{array}$ & $\begin{array}{c}8 \\
\text { BIn }\end{array}$ & & \\
\hline $\begin{array}{l}5,8 \\
\mathrm{Kg}\end{array}$ & 1 & - & - & 1 & 8,3 \\
\hline $\begin{array}{c}6,3 \\
\mathrm{Kg}\end{array}$ & - & 2 & - & 2 & 16,7 \\
\hline $\begin{array}{l}6,7 \\
\mathrm{Kg}\end{array}$ & - & - & 1 & 1 & 8,3 \\
\hline \multicolumn{4}{|c|}{ Total } & 4 & $\begin{array}{c}33 \\
\mathbf{3}\end{array}$ \\
\hline
\end{tabular}

Berdasarkan tabel diatas, setelah dilakukannya terapi pijat bayi kepada bayi berjenis kelamin perempuan didapatkan hasilnya bahwa bayi usia 6 bulan sebanyak 1 bayi $(8,3 \%)$ dengan berat badan yaitu $5,8 \mathrm{Kg}$, bayi usia 7 bulan sebanyak 2 bayi $(16,7 \%)$ dengan berat badan yaitu $6,3 \mathrm{Kg}$ dan bayi usia 8 bulan sebanyak 1 bayi (25\%) dengan berat badan yaitu $6,7 \mathrm{Kg}$.
Tabel 1.4. Hasij Uji Paired Sample Test Pada Berat Badan Bayi Sebelum Dan Sesudah Tindakan Pijat Bayi

\begin{tabular}{|c|c|c|c|c|}
\hline $\begin{array}{c}\text { Berat } \\
\text { Badan } \\
\text { Bayi }\end{array}$ & Mean & SD & n & Sig. \\
\hline $\begin{array}{c}\text { Pre-Test } \\
\text { Post- } \\
\text { Test }\end{array}$ & 1,05 & 0,929 & 12 & 0,000 \\
\hline \multicolumn{4}{|c|}{ Teknik } \\
\hline
\end{tabular}
adalah dengan dilakukan Paired Sample Test. Hal ini dilakukan untuk melihat adanya pengaruh pemberian pijat bayi terhadap perubahan berat badan bayi antara pre-test dan post-test. Hasil uji diperoleh nilai $P=0,07 \quad(P<0,05)$ dengan kata lain ada peningkatakn berat badan bayi setelah dilakukannya terapi pijat bayi dengan nilai rata-rata peningkan berat badan bayi sebesar 1,05 $\mathrm{Kg}$.

\section{4. pembahasan}

1. Berat Badan Bayi Sebelum (Pre-test) Dilakukan Pijat Bayi

Berdasarkan pengukuran berat badan bayi berjenis kelamin laki-laki sebelum dilakukan tindakan, didapatkan data bahwa usia bayi 6 bulan dengan berat badan berat badan $6,5 \mathrm{Kg}$ sebanyak 1 bayi $(8,3 \%)$ usia 7 bulan dengan berat dan $6,8 \mathrm{Kg}$ sebanyak 4 bayi dan usia 8 bulan dengan berat badan bayi $7,2 \mathrm{Kg}$ sebanyak 3 orang (25\%).

Berdasarkan pengukuran berat badan bayi berjenis kelamin perempuan sebelum dilakukan tindakan, didapatkan data bahwa usia bayi 6 bulan dengan berat badan bayi yaitu $5,7 \mathrm{Kg}$ sebanyak 1 bayi $(8,3 \%)$, usia 7 bulan dengan berat dan $6,2 \mathrm{Kg}$ sebanyak 2 bayi $(16,7 \%)$ dan usia 8 bulan dengan berat badan bayi $6,6 \mathrm{Kg}$ sebanyak 1 orang $(8,3 \%)$.

Secara teoritis, bayi memang memiliki berat badan yang bervariasi berdasarkan usia dan jenis kelaminnya. Peningkatan berat badan bayipun sangat dipengaruhi oleh berbagai faktor baik internal maupun eksternal. Karena itu, setiap bayi akan memiliki berat badan yang bervariasi tergantung dari faktor-faktor tersebut. 
2. Hasij Uji Paired Sample Test Pada Berat Badan Bayi Sebelum Dan Sesudah Tindakan Pijat Bayi

Hal ini dilakukan untuk melihat adanya pengaruh pemberian pijat bayi terhadap perubahan berat badan bayi antara pre-test dan post-test. Hasil uji diperoleh nilai $P=0,07(P<0,05)$ dengan kata lain ada peningkatakn berat badan bayi setelah dilakukannya terapi pijat bayi dengan nilai rata-rata peningkan berat badan bayi sebesar $1,05 \mathrm{Kg}$.

Hasil dari penelitian yang dilakukan oleh Merineherta (2009) yang menyatakan bahwa ada pengaruh pijat bayi terhadap peningkatan berat badan bayi usia 3-6 bulan, yaitu terdapat perbedaan yang signifikan pada bayi yang dilakukan pemijatan jauh lebih baik dari bayi yang tidak dilakukan pemijatan dengan nilai $p=<0,05$.

Penelitian lain yang dilakukan oleh Primanta (2016), pengukuran berat badan bayi setelah perlakuan pijat bayi didapatkan distribusi rata-rata berat badan responden adalah $6,56 \mathrm{~kg}$. Berat badan terendah adalah $4,8 \mathrm{~kg}$ dan berat badan tertinggi adalah $8,2 \mathrm{~kg}$ sehingga pengaruh pemberian pijat bayi selama 2 minggu dengan 6 kali perlakuan terhadap perubahan berat badan bayi dengan nilai signifikan ( $p$ ) sebesar 0,025 .

\section{KESIMPULAN}

Berdasarkan hasil dan pembahasan penelitian tentang hubungan pijat bayi dengan peningkatan berat badan bayi, maka disimpulkan bahwa :

1. Berdasarkan usia bayi, paling banyak berusia 8 bulan yaitu sebanyak 6 orang $(50 \%)$, usia 7 bulan yaitu sebanyak 4 orang $(37,5 \%)$ dan usia 6 bulan yaitu sebanyak 2 orang $(16,7 \%)$. Berdasarkan jenis kelamin bayi, paling banyak berjenis kelamin laki-laki yaitu sebanyak 8 orang $(66,6 \%)$ dan perempuan sebanyak 4 orang (33,3\%). Berdasarkan pendidikan orang tua, paling banyak berpendidikan SMA yaitu sebanyak 7 orang $(58,3 \%)$ dan SMP sebanyak 5 orang $(41,7 \%)$. Berdasarkan pekerjaan orang tua, paling banyak bekerja sebagai petani yaitu sebanyak
9 orang (75\%), PNS sebanyak 2 orang $(16,7 \%)$ dan pegawai swasta yaitu sebanyak 1 orang $(8,3 \%)$.

2. Berdasarkan pengukuran berat badan bayi berjenis kelamin laki-laki sebelum dilakukan tindakan didapatkan data bahwa usia bayi 6 bulan dengan berat badan berat badan $6,5 \mathrm{Kg}$ sebanyak 1 bayi $(8,3 \%)$ usia 7 bulan dengan berat dan $6,8 \mathrm{Kg}$ sebanyak 4 bayi dan usia 8 bulan dengan berat badan bayi $7,2 \mathrm{Kg}$ sebanyak 3 orang (25\%) dan berdasarkan pengukuran berat badan bayi berjenis kelamin perempuan sebelum dilakukan tindakan didapatkan data bahwa usia bayi 6 bulan dengan berat badan berat badan $5,7 \mathrm{Kg}$ sebanyak 1 bayi $(8,3 \%)$, usia 7 bulan dengan berat dan $6,2 \mathrm{Kg}$ sebanyak 2 bayi $(16,7 \%)$ dan usia 8 bulan dengan berat badan bayi $6,6 \mathrm{Kg}$ sebanyak 1 orang $(8,3 \%)$.

3. Setelah dilakukannya terapi pijat bayi kepada bayi berjenis kelamin laki-laki didapatkan hasilnya bahwa bayi usia 6 bulan sebanyak 1 bayi $(8,3 \%)$ dengan berat badan yaitu $6,6 \mathrm{Kg}$, bayi usia 7 bulan sebanyak 4 bayi $(33,3 \%)$ dengan berat badan yaitu $6,9 \mathrm{Kg}$ dan bayi usia 8 bulan sebanyak 3 bayi (25\%) dengan berat badan yaitu 7,3 $\mathrm{Kg}$ dan berdasarkan tabel diatas, setelah dilakukannya terapi pijat bayi kepada bayi berjenis kelamin perempuan, didapatkan hasilnya bahwa bayi usia 6 bulan sebanyak 1 bayi $(8,3 \%)$ dengan berat badan yaitu $5,8 \mathrm{Kg}$, bayi usia 7 bulan sebanyak 2 bayi $(16,7 \%)$ dengan berat badan yaitu $6,3 \mathrm{Kg}$ dan bayi usia 8 bulan sebanyak 1 bayi (25\%) dengan berat badan yaitu $6,7 \mathrm{Kg}$.

4. Hasil uji diperoleh nilai $P=0,07(P<$ $0,05)$ dengan kata lain ada peningkatakn berat badan bayi setelah dilakukannya terapi pijat bayi dengan nilai rata-rata peningkan berat badan bayi sebesar 1,05 $\mathrm{Kg}$.

5. Ada implikasi antara pijat bayi terhadap peningkatan berat badan pada bayi usia 6-8 bulan Di Desa Bakti Kecamatan Babul Makmur Kabupaten Aceh Tenggara. 


\section{DAFTAR PUSTAKA}

Adriani, M., \& Wirjatmadi, B. (2014). Gizi dan Kesehatan Balita Peranan Micro Zinc pada Pertumbuhan Balita. Jakarta: Kencana Prenadamedia Group.

Chomaria, Nurul. (2015). Tumbuh Kembang Anak Usia 0-5 Tahun. Cetakan pertama, Surakarta : Cinta.

Hidayat, Azis Alimul, (2013). Ilmu Kesehatan Anak. Jakarta : Salemba Medika.

Irva TS, Hasanah Oswati, Woferst Rismadefi. (2014). Pengaruh Terapi Pijat Terhadap Peningkatan Berat Badan Bayi Di Wilatah Kerja Puskesmas (Posyandu) Harapan Raya Pekanbaru. Jurnal PSIK Universitas Riau. JOM PSIK Vol. (1) No (2).

Merineherta. (2009). Pengaruh Pijat Bayi Terhadap Peningkatan Berat Badan Bayi Usia 3-6 Bulan di Keluraan Pasia Nan Tigo Kecamatan Koto Tangah
Kota Padang [skripsi]. Padang: Universitas Andalas.

Primanta, Anggun. (2016). Pengaruh Pijat Bayi Terhadap perubahan Berat Badan Bayi (Skripsi). Makassar. Program Studi Fisioterapi Fakultas Kedokteran Uniersitas Hasanuddi.

RISKESDAS. (2013). Badan Penelitian dan Pengembangan Kesehatan, Departemen Kesehatan, Republik Indonesia. Jakarta.

Soetjiningsih. (2014). Tumbuh Kembang Anak. Jakarta: Penerbit Buku Kedoteran EGC.

Soedjatmiko. (2013). Pedoman Praktis Pemijatan Bayi. Tangerang : Karisma Publishing Group.

Wong, Dona L. (2008). Buku Ajar Keperawatan Pediatrik Wong.Volume 1. Edisi 6. Penerbit Buku Kedokteran: EGC. 